\title{
A Study on Investors Awareness about Equity and Currency Market in Private Sectors
}

\section{OPEN ACCESS}

Manuscript ID:

MGT-2021-09013824

Volume: 9

Issue: 1

Month: July

Year: 2021

P-ISSN: 2321-4643

E-ISSN: 2581-9402

Received: 10.03.2021

Accepted: 20.04.2021

Published: 01.07.2021

Citation:

Latha, and K.S. Bhavani

Devi. "A Study on Investors Awareness about Equity and Currency Market in Private Sectors." Shanlax International Journal of Management, vol. 9, no. 1, 2021, pp. 34-38.

DOI:

https://doi.org/10.34293/ management.v9i1.3824

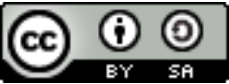

This work is licensed under a Creative Commons Attribution-ShareAlike 4.0 International License.

\section{Latha}

Associate Professor, Annamalai University, Chidambaram, Tamil Nadu, India

https://orcid.org/0000-0003-2991-0844

\section{K.S. Bhavani Devi}

Research Scholar, Annamalai University, Chidambaram, Tamil Nadu, India

\section{Abstract}

The study was conducted to examine the awareness among the investors about equity and currency market. The study was useful to identify the investors' mentality towards stock market. The researcher could gain knowledge about equity and currency market. As well, it's also helpful in creating a good relationship with the investors. At the beginning of a business, owners put some effort to finding the finance assets into the business. This creates the shape of the capital on the business liability to a separate entity from its owners. Although, the foreign exchange market is isolated comparing to other than this. Nevertheless market manipulation of central banks by the foreign exchange market has to be mentioned to the nearest ideal perfect completion.

Keywords: Awareness, Currency market, Investors' mentality, Capital, Foreign exchange

\section{Introduction}

Equity

In accounting and finance, equity is a claim to share of earnings after dept obligations have been satisfied or interest of the most junior class in assets, after the paid of all the liabilities. If the valuations placed on the assets, it does not exceed liabilities, negative equity exits. Normally shareholders equity or shareholders funds or capital or similar terms are all consider being a remaining interest of assets by a company. It would span among the individual shareholders of preferred stock for common shares. That's why; owners put some extra effort to examine the finance assets by the beginning of a business.

At the beginning of a business, owners put some effort to finding the finance assets into the business. This creates the shape of the capital on the business liability to a separate entity from its owners. The sum of liabilities assets may consider only for the accounting purposes and the positive prompting is considered by the owner's interest on the business. This definition is helpful to understand the liquidation process in case of bankruptcy. At first, all the secured creditors are paid against proceeds from assets.

\section{Equity Investment}

Equity investments are buying and holding the shares by individuals and firms for expectancy income from capital gains and revenues as the value of the stock rises from the stock markets. When a company being created or newly created, the owners were acquisition of equity or participating in a private company. Mainly the infant companies are referred to a venture capital investing the investments for capital gains. Generally they were under stood to be a higher risk than investment in listed going-concern situations. 
In India, Equity investments have some important rules for buying and holding the shares. This will leads to achieve their investments goals. Before invest the shares in a share markets, we should learn such things about the stock market. This will help to update the various trading strategies available for investors. Those five golden rules of equity investment is mentioned below.

- Rule 1: Do not give into the pressure of collective behavior

- Rule 2: To think Long-term

- Rule 3: To refrain from speculating

- Rule 4: To diversify

- Rule 5: To make a plan and stick to it

A calculation can be made to assesses whether an equity is over or under priced compared with a long-term government bond. This is called as yield or yield ratio. It is the ratio of the dividend yield of equity and that of the long-term bond.

\section{Currency Market}

The foreign exchange market (forex, fx, or currency market) is a worldwide decentralized over the counter financial market for the trading of currencies. Financial centers around the world function as anchors of trading between a wide range of different types of buyers and sellers around the clock, with the exception of weekends.

The purpose of the foreign exchange market 'forex' is to assist international trade and investment. The foreign exchange market allows businesses to covert one currency to another foreign currency.

For example, it permits a U.S business to import European goods and pay Euros, even though the business income is in U.S dollars. Some exports, however, believe that the unchecked speculative movement of currencies by large financial institutions such as hedge funds impedes the market from the correcting global current account imbalances. This carry trade may also lead to loss of competitiveness to some countries.

In a typical foreign exchange transaction a party purchases a quantity of one currency by paying a quantity of another currency. The modern foreign exchange market started forming during the 1970s when countries gradually switched to a floating exchange rates regime, which remained fixed as per the Breton woods system. The foreign exchange market is unique because of

- Trading volume results in market liquidity

- Geographical dispersion

- Continues operation; 24 hours a day except weekends, that is trading from 20:15 UTC on Sunday until 22:00 UTC Friday

- The low margins of relative profit compared with others markets of fixed income

- The use of leverage to enhance profit margins with respect to account size

\section{Objectives}

\section{Primary Objectives}

- To find the equity market awareness among investors.

- To find the currency market awareness among investors.

- To find the investors who are interested to invest in currency market.

- To achieve this task, ownership in a private corporation is sold the public in the form of shares of stock.

- To monetary policy have three main objectives growth, equity and price stability.

\section{Secondary Objectives}

- To provide the government with an easy access to foreign exchange in times of emergency.

- To help companies elevate money.

- To implement the monetary policy of the country.

- To retaliate against other countries which have imposed trade restrictions

\section{Methodology}

This study attempts to examine the investors' perceptions and awareness of equity and currency market in India. This will help to find out how much people to aware about these two markets in invest mentality. The result from the study can be used to give valuable information on the elements and dimensions, which have been given priority by the investors in assessing the quality of services and satisfactions. 


\section{Data Sources}

\section{Primary Data}

The primary data was collected through an administered Questionnaire. The questionnaire consisted of a variety of questions that were consistent with the objectives of the research.

\section{Research Questions}

- RQ1: To investigate the extant of ensure that the information needs match the objectives, which in turn match the data collected through the questionnaire.

- RQ2: To understand and prioritize the dimensions of service quality as valued by investors.

- RQ3: To assess satisfaction level of investors on various dimensions of service quality.

\section{Instrument and Measurement Scale}

The Direct- structured type of data collections method was used for data collection purpose. The interview mode was adopted for the collections of data. In this study simple random sampling techniques were used. The population of the study consists of the clients of stockbroker. The population is more suited to the simple random method. This type of sampling is also known as chance sampling or probability sampling where each and every item in the population has an equal chance of inclusion in the sample and each one of the possible samples, in the case of a finite universe, has the same probability of being selected. And the sample size is 150 .

Table 1

\begin{tabular}{|c|c|c|}
\hline Category & No of Respondents & $\%$ \\
\hline \multicolumn{3}{|l|}{ Gender } \\
\hline Male & 96 & $64 \%$ \\
\hline Female & 54 & $36 \%$ \\
\hline \multicolumn{3}{|l|}{ Age } \\
\hline Below 20 & 50 & $33 \%$ \\
\hline $20-30$ & 68 & $45 \%$ \\
\hline Above 30 & 32 & $22 \%$ \\
\hline \multicolumn{3}{|l|}{ Marital status } \\
\hline Married & 56 & $37 \%$ \\
\hline Unmarried & 94 & $63 \%$ \\
\hline \multicolumn{3}{|l|}{ Locality } \\
\hline Rural & 98 & $65 \%$ \\
\hline
\end{tabular}

\begin{tabular}{|c|c|c|}
\hline Semi-urban & 30 & $20 \%$ \\
\hline Urban & 22 & $15 \%$ \\
\hline \multicolumn{3}{|l|}{ Income Level } \\
\hline Below 10000 & 20 & 135 \\
\hline $10000-15000$ & 80 & $53 \%$ \\
\hline $15000-25000$ & 42 & $28 \%$ \\
\hline Above 25000 & 8 & $6 \%$ \\
\hline \multicolumn{3}{|l|}{ Market } \\
\hline Equity & 146 & $97 \%$ \\
\hline Commodity & 2 & $1.5 \%$ \\
\hline Currency & 2 & $1.5 \%$ \\
\hline \multicolumn{3}{|c|}{ Stockbroker they choose } \\
\hline Friends & 104 & $69 \%$ \\
\hline Advertisement & 30 & $20 \%$ \\
\hline Stockbroker & 10 & $7 \%$ \\
\hline \multicolumn{3}{|l|}{ Returns } \\
\hline $10 \%$ & 2 & $1 \%$ \\
\hline $20 \%$ & 100 & $67 \%$ \\
\hline $30 \%$ and above & 48 & $32 \%$ \\
\hline \multicolumn{3}{|c|}{ Investment Risk } \\
\hline High & 140 & $93 \%$ \\
\hline Moderate & 4 & $3 \%$ \\
\hline Low & 6 & $4 \%$ \\
\hline
\end{tabular}

\section{Chi - Square Test}

For the Null Hypothesis, there are no significant differences between income level and mode of investment.

\section{Hypothesis (H1)}

Here some significant difference between income level and mode of investment.

\begin{tabular}{|c|c|c|c|c|}
\hline $\begin{array}{c}\text { Income } \\
\text { Level }\end{array}$ & Equity & Commodity & Currency & Total \\
\hline $\begin{array}{r}\text { Below } \\
10,000\end{array}$ & 24 & 6 & 18 & 48 \\
\hline $\begin{array}{r}10,000- \\
15,000\end{array}$ & 14 & 10 & 4 & 28 \\
\hline $\begin{array}{c}15,000- \\
25,000\end{array}$ & 12 & 12 & 14 & 38 \\
\hline $\begin{array}{c}25,000 \\
\text { Above }\end{array}$ & 8 & 16 & 12 & 36 \\
\hline Total & 58 & 44 & 48 & 150 \\
\hline
\end{tabular}


Table 2: Calculation of Chi-Square

\begin{tabular}{|c|c|c|c|c|}
\hline $\begin{array}{c}\text { Observed } \\
\text { Frequency }\end{array}$ & $\begin{array}{c}\text { Expected } \\
\text { Frequency }\end{array}$ & $\mathbf{O}_{\mathbf{i}}-\mathbf{E}_{\mathbf{i}}$ & $\left(\mathbf{O}_{\mathbf{i}}-\mathbf{E}_{\mathbf{i}}\right)^{2}$ & $\begin{array}{c}\left(\mathbf{O}_{\mathbf{i}}-\mathbf{E}_{\mathbf{i}}\right)^{2} \\
/ \mathbf{E}_{\mathbf{i}}\end{array}$ \\
\hline 24 & 18.56 & 5.44 & 29.5936 & 1.594 \\
\hline 14 & 10.82 & 3.18 & 10.1124 & 0.934 \\
\hline 12 & 14.69 & -2.69 & 7.2361 & 0.492 \\
\hline 8 & 13.92 & -5.92 & 35.0464 & 2.517 \\
\hline 6 & 14.08 & -8.08 & 65.2864 & 4.636 \\
\hline 10 & 8.21 & 1.79 & 3.2041 & 0.390 \\
\hline 12 & 11.15 & 0.44 & 0.1936 & 0.017 \\
\hline 16 & 10.56 & 5.44 & 29.5936 & 2.802 \\
\hline 18 & 15.36 & 2.64 & 6.9696 & 0.453 \\
\hline 4 & 8.96 & -4.96 & 24.6016 & 2.745 \\
\hline 14 & 12.16 & 1.84 & 3.3856 & 0.278 \\
\hline 12 & 11.52 & 0.48 & 0.2304 & 0.02 \\
\hline & & & Total & 16.878 \\
\hline
\end{tabular}

Degree of Freedom: $(n-1)=(12-1)=11$

The table value of $\mathrm{X}^{2}$ for the degree of freedom at 5 percent level of significance is 19.675 . Comparing calculated and table value of $\mathrm{X}^{2}$, we find that the calculated value is less than the table value and as such could have arisen due to fluctuations of sampling. The result thus supports the hypothesis and it can be concluded that the die is unbiased.

\section{Suggestions}

It was found that the majority $97 \%$ of the investors are trading in the equity market. And the majority $69 \%$ of the investors has earned a moderate income out of their investment. And also the majority $93 \%$ of the investors has high risk towards their investment.

The majority $64 \%$ of the investors chooses their market on friends and other interests. And the majorities $96 \%$ of investors have no knowledge about currency market. And the majority $84 \%$ of the investors has no interest in knowing about the currency market and it was found that the majority $84 \%$ of the investors have no interest in trading of the currency market.

Management can concentrate on creating awareness among their investors through the relationship managers about the currency market.

Stockbrokers should have a piece of complete knowledge and should update themselves about the market moment.
Stockbrokers should encourage investors to trade in the currency market.

Benefits and low risks of currency markets should be well explained to the investors.

Management can concentrate on advertising their concern to the investors by highlighting their achievements.

If these recommendations are considered, it will definitely increase the number of investors in the company.

\section{Conclusion}

There are a lot of scopes for hexagon securities to make the investors invest both in equity and currency market by considering the above-mentioned recommendations. By way of attracting investors towards their concern, it will lead a greater income through brokerage commission out of trade. It will helps in achieving the objectives of the organization and also to expand their services to a greater extend. It may finally result in attaining their organization's vision.

\section{References}

Bhattacharjee, Jayashree, and Ranjit Singh. "Awareness about Equity Investment among Retail Investors: A Kaleidoscopic View." Qualitative Research in Financial Markets, vol. 9, no. 4, 2017, pp. 310-324.

Dubey, Surbhi, and Sameer Sharma. "Retail Investors Awareness towards Stock Market Investment." International Education \& Research Journal, vol. 5, no. 1, 2019, pp. 1214.

"Investment Guide for Beginners." IIFL Securities, https://www.indiainfoline.com/investmentguide/beginners-investment-guide

https://www.economictimes.indiatimes.com/bankof-india/stocks/companyid-11964.cms

Kothari, C.R., and Gaurav Garg. Research Methodology. New Age International Publishers, 2019.

Limaye, Vikram. "The Rise of Small-Town Investors in Indian Equity Markets." The Economic Times, 2019. 
Parker, Tim. "The Basics of Currency Trading." Investopedia, https://www.investopedia.com/ financial-edge/0412/the-basics-of-currencytrading.aspx

Saranya, R., and Kavita Poddar. "A Study on Investor's attitude towards Currency market in Chennai, Tamil nadu. India." International Journal in Multidisciplinary and Academic Research, vol. 2, no. 4, 2013.
Siva Sakthi, R., and P. William Robert. "A Study on Investors Awareness of Stock Market." IJARIIE, vol. 3, no. 6, 2017, pp. 849-854.

Vidhya, B., and S. Magesh. "Evaluation of Investor Awareness on Techniques used in Stock Trading before their Investment." International Journal of Engineering \& Technology, vol. 7, 2018, pp. 98-107.

\section{Author Details \\ Dr. Latha, Associate Professor, Annamalai University, Chidambaram, Tamil Nadu, India}

K.S. Bhavani Devi, Research Scholar, Annamalai University, Chidambaram, Tamil Nadu, India,

Email ID: bhavanidevibalaji@gmail.com 